\title{
Study on morphometric, productive and reproductive traits of native cattle at Sylhet district
}

\author{
B. Koirala, M. Z. Alam, A. Iqbal and A. K. F. H. Bhuiyan ${ }^{1}$ \\ Department of Genetic Engineering and Biotechnology, Shahjalal University of Science and Technology, Sylhet \\ ${ }^{1}$ Department of Animal Breeding and Genetics, Bangladesh Agricultural University, Mymensingh.
}

\begin{abstract}
The morphometric, productive and reproductive traits of indigenous cattle at Sylhet district were studied. A wide variety of coat colours among the cattle of the selected areas was observed. Most of them were of roan colour. The body is small, compact and less fleshy. Wither height and hearth girth were $89.03 \pm 11.11$ and $112.09 \pm 16.68 \mathrm{~cm}$, respectively. The average body length was $119.85 \pm 16.96 \mathrm{~cm}$ and the chest width was $32.48 \pm 6.48 \mathrm{~cm}$. The approximate body weight and horn size of the cattle were $162.77 \pm 60.99 \mathrm{~kg}$ and $3.94 \pm 4.05 \mathrm{~cm}$, respectively. The milk production per day was $1.33 \pm 0.4$ litres, lactation length was $187.94 \pm 14.77$ days and the dry period was $220.81 \pm 15.68$ days. Gestation length and calving interval were found to be $299.19 \pm 3.82$ days and $453.47 \pm 13.181$ days, respectively. The mean age at first calving was $44 \pm 1.6$ months. The productive and reproductive performances of native cattle of Sylhet district. More detailed studies are needed to recommend the morphometric, productive and reproductive performance of cattle in Sylhet district.
\end{abstract}

Keywords: Native cattle, Morphometric, Reproductive, Productive traits

\section{Introduction}

The cattle resources of Bangladesh are mostly of the indigenous type (Bos indicus) with a substantial number of Sindhi, Sahiwal, Jersey and Holstein-Friesian crossbreds. Indigenous cattle experience late maturity, short lactation length, long calving interval and poor production of milk and draught power but are more disease resistant and capable of thriving in harsh conditions (Majid et al., 1992). Exotic breeds often lack resistance to local diseases and climatic conditions, produce poorly and lack persistency without considerable high quality feed and management. In the developing world, indiscriminate use of exotic animal genetic resources and poorly designed breeding schemes are the major reasons for the loss of animal genetic resources. The loss of locally adapted breeds will have long-term negative implications, and in most instances, will reduce food security rather than ensure it. The loss of indigenous breeds adversely affects community identity and structure and reduces the ability of local community to maintain their traditional lifestyles. Locally adapted breeds will continue to be valuable in our countries because these countries cannot afford the inputs that are required to sustain breeds that have been developed in low stress, high input production systems (Al Amin et al. 2007).

There are a few improved varieties of cattle such as Red Chittagong, Pabna Milking cow and North Bengal Grey localized in some areas of the country. Most of the native cattle are of indigenous type and non-descript type. These so called indigenous type of cattle have neither been identified (either by phenotypic and genetic characterization) nor has any objective study been made on their conformation or productive and reproductive performance. The productive and reproductive performance of indigenous cattle all over the country has not yet been well evaluated. The documented scientific information on various traits of these cattle in north-east part of Bangladesh is still lacking, therefore the present study was undertaken to evaluate and characterize the indigenous cattle of Sylhet, Bangladesh with the following objectives: (i) to morphologically characterize the native cattle and (ii) to assess their productive and reproductive performances.

\section{Materials and Methods}

Sylhet District is located in north-east part of Bangladesh. It is located between $24^{\circ} 55^{\prime} 12^{\prime \prime}$ o $\mathrm{N}$ latitude and ' $92^{\circ} 00^{\prime} 00^{\prime \prime}{ }^{\circ} \mathrm{E}$ longitude. The city is within the monsoon climate zone, with annual average highest temperatures of $23^{\circ} \mathrm{C}$ (Aug-Oct) and average lowest temperature of $7^{\circ} \mathrm{C}$ (Jan). Extreme temperatures 
range between about $7^{\circ} \mathrm{C}$ and $41^{\circ} \mathrm{C}$. The mean altitude of Sylhet from the sea level is 15 feet. The three Upazilas namely Jayantapur, Sylhet Sadar and Bishownath under Sylhet district were selected. The data collection sheet and questionnaire was carefully designed contained both open and closed form questions. The data collection sheet was designed and pre tested. Simple and direct questions were included in the questionnaire for collecting information relating to such characteristics of the animal as production potential, reproductive characteristics and morphometric characteristics. A total of 500 animals were selected from three Upazilas (Jayantapur, Sylhet Sadar and Bishownath). Animals were selected randomly as milking cow, heifers, bulls and calf.

Collection of data from the field was done cautiously since the reliability of survey depends on the authenticity of the data to be obtained. Interview technique was followed to collect relevant information. All possible efforts were made to ensure the collection of accurate information from the field. The information was checked carefully and any confusion was rationalized and corrected by comparing those with local standards to keep consistency of data.

\section{Results and Discussion}

\section{Morphometric traits}

The morphometric characteristics of the indigenous cow of Sylhet such as coat colour, height at wither, hearth girth, body length, chest width and horn size are shown in Table 1.

Coat colour: The coat colour of the indigenous cattle of Sylhet shows a great variety (Table 1). Out of 500 cattle $43.4 \%$ was of roan colour, $16.2 \%$ cattle were of black coat colour, $12.5 \%$ was white, $8.8 \%$ was brown, $7.6 \%$ was dark brown, $7.8 \%$ was light brown, $3 \%$ was red, $0.4 \%$ of each ash and grey and $0.2 \%$ cream coat colour was observed.

Table 1. Morphometric characteristics of native cattle of Sylhet district of Bangladesh

\begin{tabular}{|l|c|c|c|c|}
\hline \multicolumn{1}{|c|}{ Traits } & Category & Minimum & Maximum & Mean \pm SE \\
\hline Wither height & Cow & 73.5 & 122.5 & $93.36 \pm 0.49$ \\
$(\mathrm{~cm})$ & Bull & 58.8 & 110.3 & $85.26 \pm 0.94$ \\
& Heifers & 58.80 & 100.45 & $77.14 \pm 1.24$ \\
& Overall & 58.80 & 122.50 & $89.03 \pm 0.49$ \\
\hline Heart girth & Cow & 88.20 & 134.75 & $118.97 \pm 0.59$ \\
$(\mathrm{~cm})$ & Bull & 66.2 & 164.2 & $106.66 \pm 1.6$ \\
& Heifers & 58.80 & 120.05 & $92.15 \pm 1.83$ \\
& Overall & 58.80 & 164.15 & $112.09 \pm 0.74$ \\
\hline Body length & Cow & 93.10 & 159.25 & $126.41 \pm 0.72$ \\
$(\mathrm{~cm})$ & Bull & 75.95 & 159.66 & $114.01 \pm 1.51$ \\
& Heifers & 66.15 & 134.75 & $102.10 \pm 1.99$ \\
& Overall & 66.15 & 159.25 & $119.85 \pm 0.75$ \\
\hline Chest width & Cow & 22.05 & 58.80 & $35.03 \pm 0.25$ \\
$(\mathrm{~cm})$ & Bull & 17.15 & 53.90 & $30.17 \pm 0.61$ \\
& Heifers & 12.25 & 36.75 & $25.62 \pm 0.75$ \\
& Overall & 12.25 & 68.80 & $32.48 \pm 0.28$ \\
\hline Horn size & Cow & 00 & 14.70 & $5.26 \pm 0.23$ \\
$(\mathrm{~cm})$ & Bull & 00 & 12.2 & $3.89 \pm 0.30$ \\
& Heifers & 00 & 2.45 & $0.14 \pm 0.07$ \\
& Overall & 00 & 14.70 & $3.94 \pm 0.18$ \\
\hline
\end{tabular}


Wither height: The average wither height of indigenous cattle of Sylhet was $89.03 \pm 11.14 \mathrm{~cm}$. Al Amin et al. (2007) observed the mean wither height of $91 \pm 10.4 \mathrm{~cm}$ in North Bengal Grey cattle, which is similar to present finding. Karthickeyan et al. (2006) observed the mean wither height of Krishna valley cattle of India to be $116.4 \pm 1.2 \mathrm{~cm}$ in cow and $150.5 \pm 0.5 \mathrm{~cm}$ in bull. The mean wither height in cow was $93.36 \pm 8.62$ $\mathrm{cm}$ and bull was $85.26 \pm 10.63 \mathrm{~cm}$, which are smaller than that of Krishna valley cattle of India. Habib et al. (2003) observed the mean body height of $107.71 \pm 0.93 \mathrm{~cm}$ in Red Chittagong cow, which is slightly higher than that of indigenous cow of Sylhet.

Hearth girth: The average hearth girth observed in indigenous cattle of Sylhet was $112.09 \pm 16.68 \mathrm{~cm}$ (Table- 1). Al Amin et al. (2007) observed the average hearth girth of $117.8 \pm 18.5 \mathrm{~cm}$, which is similar to our present finding. Habib et al. (2003) observed the hearth girth of $139.85 \pm 1.63 \mathrm{~cm}$ in Red Chittagong cow and Karthickeyan et al. (2006) observed the mean chest girth of Krishna valley cow of India to be $144.7 \pm 2 \mathrm{~cm}$, which are higher than that of indigenous cow of Sylhet.

Body length: It has been observed from Table 1 that the mean body length of native cattle of Sylhet was $119.85 \pm 16.69 \mathrm{~cm}$. Karthickeyan et al. (2006) observed the mean body length of Krishna valley cattle to be $128.4 \pm 2 \mathrm{~cm}$ which is slightly higher than that of present finding. Habib et al. (2003) observed the mean body length of Red Chittagong cow to be $114.38 \pm 1.56 \mathrm{~cm}$ which is smaller than that of native cow of Sylhet. Al Amin et al. (2007) found the average body length of North Bengal Grey cattle to be $99 \pm 13.8 \mathrm{~cm}$ which is smaller then that of present finding. It suggests that indigenous cattle of Sylhet are slightly longer in length than North Bengal Grey cattle of Bangladesh.

Chest width: The mean chest width $32.48 \pm 6.45 \mathrm{~cm}$ in native cattle of Sylhet was the observed mean chest width in cow, bull and heifers were $35.03 \pm 4.45,30.17 \pm 6.95$ and $25.62 \pm 6.45 \mathrm{~cm}$, respectively.

Horn size: The mean horn sizes of native cattle of Sylhet is presented in Table 1. The observed mean horn size of native cattle of Sylhet was $3.94 \pm 4.05 \mathrm{~cm}$. The maximum and minimum horn size lengths observed were 14.70 and $0.61 \mathrm{~cm}$, respectively. The horns were of different shape and size including bent and with sharp tip.

Productive traits: The productive traits of native cattle of Sylhet such as approximate body weight, daily milk yield and lactation length are given in Table 2.

Table 2. Reproductive and productive characteristics of native cattle of Sylhet

\begin{tabular}{|c|c|c|c|c|c|}
\hline Traits & Category & No. & Minimum & Maximum & Mean \pm SE \\
\hline $\begin{array}{l}\text { Age at first calving (Years) } \\
\text { Calving interval (days) }\end{array}$ & $\begin{array}{l}\text { Cow } \\
\text { Cow }\end{array}$ & $\begin{array}{c}27 \\
303 \\
\end{array}$ & $\begin{array}{c}3 \\
430 \\
\end{array}$ & $\begin{array}{l}4.5 \\
520\end{array}$ & $\begin{array}{c}3.68 \pm 0.08 \\
453.47 \pm 0.69 \\
\end{array}$ \\
\hline $\begin{array}{l}\text { Daily milk yield } \\
\text { (litreslday) }\end{array}$ & Cow & 303 & 1 & 3 & $1.3317 \pm 0.023$ \\
\hline $\begin{array}{l}\text { Gestation length } \\
\text { ( days) }\end{array}$ & Cow & 303 & 270 & 320 & $299.19 \pm 0.22$ \\
\hline $\begin{array}{l}\text { Lactation length } \\
\text { ( days) }\end{array}$ & Cow & 303 & 180 & 240 & $187.94 \pm 0.85$ \\
\hline $\begin{array}{l}\text { Dry period } \\
\text { (days) }\end{array}$ & Cow & 303 & 180 & 255 & $220.81 \pm 0.901$ \\
\hline $\begin{array}{l}\text { Approx. body wt. } \\
(\mathrm{kg})\end{array}$ & $\begin{array}{l}\text { Cow } \\
\text { Bull } \\
\text { Heifers } \\
\text { Overall }\end{array}$ & $\begin{array}{c}303 \\
127 \\
70 \\
500\end{array}$ & $\begin{array}{c}89.7 \\
43.63 \\
23.56 \\
23.56\end{array}$ & $\begin{array}{l}279.58 \\
442.09 \\
200.08 \\
442.10\end{array}$ & $\begin{array}{c}186.88 \pm 2.52 \\
141.99 \pm 6.12 \\
96.04 \pm 5.20 \\
162.77 \pm 2.72\end{array}$ \\
\hline
\end{tabular}


Body weight: The mean approximate body weights of indigenous cattle of Sylhet are presented in Table 2. Al Amin et al. (2007) observed the mean body weight of North Bengal Grey cow of Pabna district to be $241 \pm 13.1 \mathrm{~kg}$ which is higher than the present finding $186.88 \pm 43.93 \mathrm{~kg}$. Khan et al. (2000) found that the mature body weight of Red Chittagong cows were 234.28 and $206.50 \mathrm{~kg}$, respectively under farm and rural conditions which is higher than the results obtained in the present study.

Daily milk yield: The mean daily milk yield is presented in the Table 2 . The mean milk yield per day was $1.33 \pm 0.408$ litre. The maximum and minimum milk yield per day was 3.0 and 1.0 litres, respectively. Habib et al. (2003) found milk yield per day of Red Chittagong cow to be $2.55 \pm 0.11$ litres. Khan et al. (2000) observed an average daily milk yield under farm and rural conditions to be $2 \pm 0.65 \mathrm{~kg}$ and $1.80 \pm 0.87 \mathrm{~kg}$, respectively which is slightly higher than the result of present study. From available studies a wide variation in milk yield of indigenous cows has been noticed and providing hints for an opportunity of selection among the indigenous cattle resources to increase milk yield in Bangladesh. Difference in genetic architecture, feeding system, quality and quantity of ration, milk man and time of milking may be affecting the daily milk yield of indigenous cow.

Lactation length: The average lactation length of native cows of Sylhet was $187.94 \pm 14.77$ days. The highest and lowest value of lactation length was found to be 240 and 180 days, respectively. Zafar et al. (2008) observed the mean lactation length of $267 \pm 2.29$ days in case of Pakistani Sahiwal cows during different periods. Al Amin et al. (2007) observed the mean lactation length of North Bengal Grey cattle of Bangladesh to be $219 \pm 38.2$ days. These results are higher than that of the present finding. Gaur et al. (2003) reported the mean lactation length of Gir cattle breed of India was $326 \pm 11$ days which is higher than that in the present study.

\section{Reproductive traits}

The reproductive characteristics (age at first calving, calving interval, gestation length, and dry period) are shown in Table 2.

Gestation length: It has been observed from the Table 2 that the average gestation length of indigenous cow of Sylhet was 299.19 \pm 3.12 days. The highest gestation length was 320 days and the lowest was 270 days. Al Amin et al. (2007) observed the overall gestation length for North Bengal Grey cows to be $281 \pm 1.3$ days. Kahn et al. (1999) and Majid et al. (1992) found the gestation length of Red Chittagong cows to be $281.30 \pm 1.43$ and $281 \pm 2.94$ days, respectively. These results are lower than that of present finding. The gestation length is a species characteristic. The duration of gestation is genetically determined. Variation may be due to maternal influence. A little variation in gestation length within the individual in different animals may be contributed mainly by maternal and fetal factors. Ages of the dam, nutritional body conditions of the dam are maternal factors. On the other hand, fetal factors include the sex and genetic makeup of the fetus, twining and hormonal functions of the fetus. Environmental factors such as season, temperature, feeding and management may also contribute to a little extent. (Al Amin et al., 2007).

Age at first calving: The average age at first calving of indigenous cow of Sylhet was $3.68 \pm 0.489$ years. The maximum and minimum age at first calving of indigenous cattle of Sylhet was 3 and 4.5 years, respectively (Table 2). Gaur et al. (2003) observed the age at first calving of Gir cattle breed of India to be $1533 \pm 56$ day (4.2 years) which is much higher than the result of present study. Al Amin et al. (2007) observed the mean age at first calving of North Bengal Grey cattle to be $1190.70 \pm 19.67$ days (3.27 years). This result is partially agreeable with the finding of present study. Genetic and management factors specially feeding system and care might have influenced this trait.

Calving interval: The overall calving interval of the present study was $453.47 \pm 13.181$ days. The maximum and minimum calving intervals were 520 and 430 days, respectively. Habib et al. (2003) found the mean calving interval of Red Chittagong cow to be $409.9 \pm 17.8$ days which is lower than those in the present study. Zafar et al. (2008) found the mean calving interval of Sahiwal cow of Pakistan to be $429 \pm 3.74$ days which is also lower than those in the present study. Calving interval varies due to maternal and environmental factors such as feeding, management, fertility etc. (Al Amin et al., 2007). 
Dry period: The mean dry period of native cow of Sylhet is presented in Table 2. The mean dry period was observed to be $220.81 \pm 15.68$ days. Al Amin et al. (2007) observed the mean dry period of $180 \pm 42.4$ days in case of North Bengal Grey cows. Zafar et al. (2008) observed the mean dry period of $152 \pm 3.76$ days in case of Pakistani Sahiwal cows. The above findings are smaller than that found in the present study.

\section{Conclusion}

From the result of this experiment it is difficult to draw conclusion regarding the productive and reproductive performances of native cattle of Sylhet district. More in-depth studies are needed to compare the production and reproductive performances of native cattle of Sylhet district with other indigenous cattle of Bangladesh.

\section{References}

Al-Amin, M., Nahar, A., Bhuiyan, A.K.F.H., and Faruque, M.O. 2007. On farm characterization and present status of North Bengal Grey (NBG) cattle in Bangladesh. AGRI. 40: 55-64.

Gaur, G.K., Kaushik, S.N. and Garg, R.C. 2003. The Gir cattle breed of India. Characteristics and present status. AGRI. 33:21-29.

Habib, M.A., Bhuiyan, A.K.F.H., Bhuiyan, M.S.A. and Khan, A.A. 2003. Performance of Red Chittagong cattle in Bangladesh Agricultural University Dairy Farm. Bang. J. Anim. Sci. 32(1-2): 101-108.

Islam, M.S., Mazed, M.A., Rahman, M.M., Islam, M.A. and Kadir, M.A. 2004. A study on some productive parameters of Local X Friesian Upgraded Dairy cows. J. Anim. And Vet. Adv. 3(9):560-563.

Karthickeyan, S.M.K., Saravanan, R. and Thangaraju, P. 2006. Krishna Valley cattle in India: status, characteristics and utility. AGRI. 39: 25-37.

Khan, M.K.I., Haque, K.S., Miah, A.G. and Khatun, M.J. 2000. Study on the performance of Red Chittagong cows under different production system. Pak. J. Bio. Sci. 3(2): 318-319.

Khan, A.A., Ali, A., Hussain, S.S and Bhuiyan, A.K.F.H. 1999. Reproductive performance of different genetic group of cows under farm condition. Bang. J. Anim. Sci. 28(1-2): 59-64.

Majid, M.A., Nahar, T.N. and Jalil, M.A. 1992. Breeding for cattle improvement in Bangladesh. Procedding fourth national conference, Bangladesh Animal Husbandry Association. pp. 169-181.

Zafar, A.H., Ahmad, M., and Rehman, S.U. 2008. Study of some performance traits in Sahiwal cows during different periods. Pak. Vet. J. 28(2): 84-88. 